\title{
IMPLEMENTASI PENDIDIKAN POLITIK DALAM MEMBENTUK KARAKTER KEPEMIMPINAN LINTAS BUDAYA PADA GENERASI MUDA DEMI MEWUJUDKAN BUDAYA POLITIK PANCASILA (Studi Deskriptif terhadap Organisasi Kepemudaan Gerakan Pemuda Ansor Jawa Barat)
}

\author{
Aris Riswandi Sanusi, Cecep Darmawan
}

Departemen Pendidikan Kewarganegaraan, SPs, UPI, email: arisriswandisanusi@yahoo.com

\begin{abstract}
The young generation is an essential element in a state life. The role of youth, as contained in Law of the Republic of Indonesia No. 40 Year 2009 on Youth that says "youths play an active role as a moral force, social control, and agents of change in all aspects of national development". However, the reality of the situation is that there has been a moral degradation and the decreasing of crosscultural leadership character in the younger generation. Political education as what Ansor PW GP of West Java implemented is one of many attempts to form a cross-cultural leadership character in young generation in order to create Pancasila political culture.
\end{abstract}

Keywords: political education, cross-cultural leadership, Pancasila political culture, Ansor PW GP of West Java.

\section{PENDAHULUAN}

Generasi muda memiliki posisi dan peran yang sangat vital dalam kehidupan kebangsaan Indonesia. Hal ini didasarkan pada peran pemuda seperti yang dimuat dalam UU RI No. 40 tahun 2009 tentang Kepemudaan yang berbunyi pemuda berperan aktif sebagai kekuatan moral, kontrol sosial, dan agen perubahan dalam segala aspek pembangunan nasional. Peran pemuda menjadi salah satu kunci terlahirnya negara Indonesia yang menjunjung tinggi nilai-nilai persatuan di atas kemajemukan bangsa Indonesia. Hal ini dapat dibuktikan dari beberapa peristiwa sejarah Indonesia yang memberikan gambaran tentang vitalnya peran pemuda yaitu peristiwa sejarah Sumpah Pemuda pada tanggal 28 Oktober 1928 yang menjadi kunci terbentuknya kekuatan pemuda untuk bersatu melawan penjajahan kolonial Belanda. Peristiwa lain diantaranya yaitu perjuangan pemuda pada era orde lama dan akhir orde baru.

Permasalahan yang mendera generasi muda menjadi latar belakang diperlukannya pendidikan politik bagi warga negara Indonesia. Pendidikan politik memiliki peran penting dalam menciptakan bangsa yang melek politik serta membentuk karakter dan perilaku warga negara. Pendidikan politik berpotensi untuk membentuk karakter, watak, dan tanggung jawab warga negara yang demokratis sehingga dapat mencapai peradaban bangsa yang lebih maju. Peran pendidikan politik menjadi lebih penting karena memiliki peran sebagai alat distribusi nilai kebangsaan bagi generasi muda yang memiliki posisi sangat vital dalam kehidupan kebangsaan, pendidikan politik sangat diperlukan untuk diselenggarakan. Hal ini didasarkan pada peran pemuda seperti yang dimuat dalam UU No. 40 tahun 2009 tentang kepemudaan yang berbunyi "pemuda berperan aktif sebagai kekuatan moral, kontrol sosial, dan agen perubahan dalam segala aspek pembangunan nasional". Peran penting pemuda inilah menjadi alasan utama dalam penyelenggaraan pendidikan politik bagi generasi muda. Pendidikan politik sangatlah penting bagi generasi muda agar dalam kehidupan bernegara bisa menjadi partisipan yang bertanggung jawab, sehingga bisa memahami proses penggunaan kekuasaan dalam menegakan aturan dalam masyarakat dan masyarakat secara umum dapat menggunakan hak politiknya. 
Selain itu, pendidikan politik menjadi sarana membentuk karakater kepemimpinan pada generasi muda. Hilangnya karakter kepemimpinan menjadi masalah tersendiri pada generasi muda sehingga harus menjadi agenda berikutnya dalam penyelenggaraan pendidikan politik. Dalam suasana Indonesia yang terdiri atas masyarakat majemuk, perlu adanya sosok kepemimpinan antarbudaya pada generasi muda sehingga mampu menjalankan peran kepemimpinan yang demokratis dalam kondisi bangsa Indonesia yang multikultural dan plural. Pendidikan politik pula ditujukan sebagai sarana menciptakan generasi muda yang mampu memerankan posisi politisnya dan mampu menjadi seorang pemimpin yang sesuai dengan nilai-nilai luhur bangsa Indonesia seperti yang terkandung dalam Pancasila. Pendidikan politik dalam hal ini ditujukan untuk membentuk generasi muda yang mampu menjadi pemimpin demi terciptanya budaya politik Pancasila.

Kantaprawira (1984, hlm. 29), budaya politik tidak lain adalah pola tingkah laku individu dan orientasinya terhadap kehidupan politik yang dihayati oleh anggota sistem politiknya. Dalam kacamata Indonesia, Pancasila sebagai ideologi sekaligus sumber utama kehidupan mengilhami terciptanya suasana dan sistem politik yang berasaskan pada nilai-nilai Pancasila. Hal ini mendorong untuk terciptanya budaya politik Pancasila dalam dinamika politik Indonesia. Hal tersebut mengilhami kita agar pendidikan politik Indonesia ditujukan untuk menciptakan generasi muda yang mampu menjalankan peran dan posisi politisnya dalam suasana budaya politik Pancasila sehingga terciptanya iklim demokrasi yang menuntut partisipasi warga negara yang bernafaskan Pancasila.

Salah satu sarana penyeleggaraan pendidikan politik tersebut adalah melalui organisasi kepemudaan sebagai langkah pemberdayaan generasi muda. Ada banyak organisasi kepemudaan yang menyelenggarakan pendidikan politik tersebut diantaranya adalah Gerakan Pemuda Ansor. GP Ansor merupakan organisasi kepemudaan Islam yang merupakan afiliasi dengan Nahdhatul Ulama yang berkomitmen terhadap sistem kenegaraan yang berpegang teguh terhadap Pancasila. GP Ansor sebagai organisasi kepemudaan Islam dan berkomitmen terhadap Pancasila dirasa sangat tepat untuk melakukan penelitian ini dalam membentuk karakter kepemimpinan lintas budaya pada generasi muda karena sebagai organisasi Islam maka dituntut untuk merealisasikan visi Islam yaitu rahmatan lil 'alamin (rahmat bagi seluruh alam) salah satunya membentuk pemimpin lintas budaya ini.

Penyelenggaraan pendidikan politik dalam organisasi kepemudaan merupakan salah satu cara yang harus dilakukan dalam dinamika politik Indonesia terlebih ditujukan kepada para generasi muda demi menyongsong masa depan politik Indonesia. Windari (2013, hlm. 10-11) berpendapat:

Sikap kritis, idealis, inovatif, solider, dan semangat juang tinggi merupakan potensi yang dimiliki pemuda. Sehingga dengan adanya organisasi pemuda, sikap positif ini akan mendorong kegiatan positif untuk nantinya akan mampu menciptakan generasi penerus bangsa yang memegang jabatan tinggi menggantikan pemimpin lama ataupun seniornya.

Hal ini memberikan penekanan bahwa organisasi kepemudaan memiliki peran yang sangat penting dalam membentuk dan mengembangkan potensi generasi muda terlebih dalam pemahaman politik generasi muda melalui pendidikan politik. Terlebih, berkaca dari realita yang terjadi tentang masalahmasalah yang mendera generasi muda menjadikan bomerang bagi bangsa Indonesia. Hal ini mengharuskan dilaksanakannya pendidikan kebangsaan yang berdasarkan nilainilai Pancasila. Hal ini pula memberi sumbangsih besar terhadap penyelenggaraan pendidikan politik yang berdasar pada nilai-nilai 
Pancasila sehingga mampu membentuk karakter Pancasila bagi para generasi muda.

Berdasarkan hal tersebut, peneliti terdorong untuk meneliti proses pendidikan politik yang diselenggarakan organisasi kepemudaan GP Ansor yang dianggap memiliki peran besar dalam kehidupan perpolitikan Indonesia dan menciptakan generasi muda yang memiliki tanggung jawab dan berpegang teguh pada nilai-nilai luhur kebangsaan Indonesia. Hal inilah yang menarik untuk dijadikan sebuah penelitian berjudul "Implementasi Pendidikan Politik dalam Membentuk Karakter Kepemimpinan Lintas Budaya pada Generasi Muda demi Mewujudkan Budaya Politik Pancasila" terhadap organisasi kepemudaan Gerakan Pemuda Ansor Jawa Barat.

Rumusan masalah penelitian sebagai berikut: 1) Bagaimana cara pandang organisasi kepemudaan GP Ansor Jawa Barat dalam memaknai pendidikan politik, kepemimpinan lintas budaya, dan budaya politik Pancasila? 2) Bagaimana peran organisasi kepemudaan GP Ansor Jawa Barat dalam membentuk karakter kepemimpinan lintas budaya pada generasi muda yang berasaskan pada nilai-nilai Pancasila melalui penyelenggaraan pendidikan politik? 3) Bagaimana metode pembelajaran politik di GP Ansor Jawa Barat dalam membentuk karakter kepemimpinan lintas budaya dalam mewujudkan budaya politik Pancasila? 4) Apa kendala yang dihadapi dalam penyelenggaraan pendidikan politik generasi muda di GP Ansor Jawa Barat? 5) Bagaiamana upaya untuk mengatasi kendala dalam penyelenggaraan pendidikan politik generasi muda di GP Ansor Jawa Barat?

Tujuan pokok dari penelitian ini yaitu 1) Untuk mengetahui cara pandang organisasi kepemudaan GP Ansor Jawa Barat dalam memaknai pendidikan politik, kepemimpinan lintas budaya, dan budaya politik Pancasila, 2) Untuk mengetahui peran organisasi kepemudaan GP Ansor Jawa Barat dalam membentuk karakter kepemimpinan lintas budaya pada generasi muda yang berasaskan pada nilai-nilai Pancasila melalui penyelenggaraan pendidikan politik, 3) Untuk mengetahui metode pembelajaran politik di GP Ansor Jawa Barat dalam membentuk karakter kepemimpinan lintas budaya dalam mewujudkan budaya politik Pancasila, 4) Untuk mengetahui upaya untuk mengatasi kendala dalam penyelenggaraan pendidikan politik generasi muda di GP Ansor Jawa Barat.

\section{METODE PENELITIAN}

Pendekatan penelitian menggunakan kualitatif untuk meneliti kehidupan suatu sistem organisasi kepemudaan. Metode penelitian menggunakan metode deskriptif untuk menggambarkan proses pendidikan politik dalam organisasi sebagai upaya membentuk karakter kepemimpinan lintas budaya demi terciptanya budaya politik Pancasila pada generasi muda.

Partisipan penelitian ini adalah ketua umum PW GP Ansor, sekretaris, bendahara, dua orang wakil ketua, dan wakil sekretaris. Lokasi penelitian ini yaitu sekretariat PW GP Ansor Jawa Barat yang beralamat J1. Pasir Salam No. 9A Kelurahan Ancol Kecamatan Regol Kota Bandung. Teknik pengumpulan data menggunakan observasi, wawancara, dokumentasi. Validitas penelitian dengan menggunakan triangulasi sumber dan teknik penelitian. Analisis data menggunakan analisis data kualitatif yang dilakukan secara interaktif dan berlangsung secara terus menerus sampai tuntas dengan tahapan data reduction, data display, dan conclusion drawing / verification.

\section{HASIL DAN PEMBAHASAN}

\section{Cara pandang organisasi kepemudaan GP Ansor Jawa Barat dalam memaknai pendidikan politik, kepemimpinan lintas budaya, dan budaya politik Pancasila}

Pendidikan politik sebagai upaya untuk memberikan pemahaman politik bagi para kader 
Ansor secara khusus dan warga NU secara umum sehingga mampu berpikir dan berperilaku beradasar pada pengamalan nilainilai Aswaja dan Pancasila. Pendidikan politik sebagai upaya menciptakan pemimpin lintas budaya dapat dimaknai sebagai upaya membentuk kader Ansor yang memiliki pemahaman lintas budaya sehingga mampu menjadi sosok seorang pemimpin seperti demikian maupun melalui pemahaman tersebut setidaknya kader Ansor dapat memberikan penilaian dan analisis terhadap pemimpin yang telah ada dan calon pemimpin yang hendak mengikuti pemilihan umum atau dengan kata lain kader menjadi pemilih yang cerdas. Karakter pemimpin lintas budaya dirasa penting dan senada dengan komitmen NU dan Ansor terhadap Indonesia beserta seluruh kekayaan bangsanya. Kepemimpinan lintas budaya merupakan karakter yang dibentuk melalui pendidikan politik sehingga kader dapat mengaplikasikan prinsip Rahmatal lil 'alamin dalam kehidupan berbangsa dan bernegara baik dalam posisi kader sebagai seorang pemimpin maupun masyarakat pada umumnya. Dengan penanaman karakter kepemimpnan lintas budaya tersebut, dapat membangun suatu budaya politik sebagai strategi mencapai tujuan kebangsaan Indonesia yang berlandas pada nilai-nilai bangsa Indonesia yaitu politik yang berketuhanan, berperikemanusiaan, demokrasi, dan berpegang pada nilai keadilan.

\section{Peran organisasi kepemudaan GP Ansor Jawa Barat dalam membentuk karakter kepemimpinan lintas budaya pada generasi muda yang berasaskan pada nilai-nilai Pancasila melalui penyelenggaraan pendidikan politik}

GP Ansor harus mampu membangun generasi muda unggul yang mampu mengamalkan nilai-nilai Islam dan Pancasila dalam setiap perilakunya, salah satunya melalui penyelenggaraan pendidikan politik. peran PW GP Ansor Jawa Barat dalam menyelenggarakan pendidikan politik adalah untuk membentuk karakter kepemimpinan pada setiap diri kader. Hal ini diyakini bahwa apabila setiap kader memiliki karakter kepemimpinan maka memberikan peluang yang sangat besar untuk mampu membimbing dirinya menjadi lebih baik. Begitu pula apabila menduduki kursi kekuasaan sebagai seorang pemimpin maka ia kan mampu membawa bangsa Indonesia ke arah perubahan yang lebih baik. NU sebagai organisasi Islam sangat mendukung syariat Islam untuk dijadikan dasar negara Indonesia, namun dengan kondisi sosial masyarakat Indonesia dan nilai-nilai yang terkandung dalam Pancasila merupakan nilai-nilai yang terkandung pula dalam Al-Qur'an.

Pelatihan kepemimpinan kader merupakan upaya menanamkan karakter kepemimpinan pada diri kader sehingga mampu menjalankan perannya sebagai warga NU dan Indonesia. Pelatihan kepemimpinan adalah agenda GP Ansor yang dianggap memberi kontribusi yang besar terhadap pembentukan generasi muda yang unggul. Contoh peran aktif GP Ansor dalam penyelenggaraan pendidikan politik untuk membentuk karakter kepemimpinan dibuktikan pada posisi ketua PW GP Ansor periode ini adalah mantan anggota DPRD Kabupaten Sumedang dan mengikuti pertarungan politik dalam pemilihan kepala daerah Kabupaten Sumedang. Begitu sekretaris saat ini menduduki posisi ketua KPU Kabupaten Purwakarta. Pendidikan politik bertujuan membentuk generasi muda yang memiliki kesadaran menuju pada tingkah laku yang baik salah satunya pembentukan karakter kepemimpinan menjadi agenda Ansor dalam membentuk generasi muda yang unggul. Peran GP Ansor adalah membentuk generasi muda Ansor memiliki karakter kepemimpinan yang mencerminkan prinsip-prinsip umat terbaik atau yang disebut Mabadi Khaira Ummah. Distribusi kader merupakan langkah selanjutnya dari rangkaian pendidikan politik di PW GP Ansor. 
Metode pembelajaran politik di GP Ansor Jawa Barat dalam membentuk karakter kepemimpinan lintas budaya dalam mewujudkan budaya politik Pancasila

Menciptakan pemimpin lintas budaya bagi para kader haruslah dibekali pemahaman awal dan mendasar terkait kepemimpinan dan materi ke-Indonesia-an. program pendidikan politik yang diselenggarakan GP Ansor seperti diungkap N1 yaitu Pelatihan Kepemimpinan Dasar (PKD) yang menjadi kewenangan Pimpinan Cabang (PC) GP Ansor pada tingkat kabupaten/kota sedangkan Pimpinan Wilayah (PW) GP Ansor pada tingkat provinsi bertugas memfasilitasi, asistensi, dan pendampingan. Namun PKD ini dalam kondisi tertentu dapat menjadi kewenangan PW GP Ansor sebagai penyelenggara. Pembelajaran politik dalam program PKL yang diselenggarakan oleh PW GP Ansor terletak pada materi-materi pokok yang diberikan yaitu Ahlussunnah wal jama'ah II, ke-NU-an II, ke-GP Ansor-an II, kepemimpinan efektif, manajemen organisasi, komunikasi, kerjasama dan networking, pengambilan keputusan dan pemecahan masalah, manajemen konflik, dan lobby dan negosiasi. PKL merupakan lanjutan dari PKD yang mencakup materi pokok yaitu Ahlussunnah wal jama'ah I, ke-Indonesiaan dan kebangsaan, ke-NU-an I, ke-GP Ansor-an I, amaliyah dan tradisi keagamaan NU, dan pengantar dasar keorganisasian. Selain materi pokok tersebut, dapat ditambahkan materi muatan lokal atau materi pendukung meliputi materi-materi disesuaikan dengan kebutuhan lokal, potensi daerah, dan kepentingan kaderisasi di daerah yang bersangkutan.

Adapun metode pembelajaran meliputi ceramah, brainstorming, diskusi, focus group discussion (FGD), game dan dinamika kelompok, penugasan, studi kasus, praktek, rihlah/turun lapangan, dan pengamatan proses melalui pendekatan pedagogi dan andragogi. Pengembangan kader dilakukan dalam bentuk diskusi, kursus aswaja, pelatihan kepemimpinan, pendidikan bela negara, pelatihan kecakapan hidup, pelatihan BMT (Baitul Maal wa Tamwil), pelatihan pengembangan profesi, dan pelatihan pengembangan kader sesuai kebutuhan. Pendidikan politik merupakan bentuk upaya berkesinambungan tidak cukup sebatas dalam tahapan kaderisasi dengan materimateri tertentu namun harus berlanjut pada tahap pengembangan sehingga kader dapat berlanjut pada pelatihan yang lebih praksis.

\section{Kendala yang dihadapi dalam penyeleng- garaan pendidikan politik generasi muda di GP Ansor Jawa Barat}

Beberapa kendala yang dihadapi adalah sikap apatis dari masyarakat NU. Salah satu kelemahan NU adalah belum bisa bersatunya seluruh masyarakat NU sehingga sistem yang dibangun belum kuat. Apatisme menjadi kendala mendasar yang terjadi pada masyarakat NU sampai saat ini. Kendala selanjutnya terletak pada pendanaan organisasi terlebih terkait orientasi personal yang pragmatis banyak kader yang justru mementingkan kepentingan pribadinya menjadikan GP Ansor sebagai media untuk mencapai kekuasaan. Kemudian, mengingat kader Ansor di setiap daerah terhitung relatif banyak, menuntut efektifias pendistribusian kader yang dihadapkan pada kapasitas, potensi dan kompetensi kader yang beraneka ragam sehingga memerlukan waktu untuk bisa mendistribusikan secara tepat. Terakhir, kedala yang dihadapi adalah pemerintah yang dirasakan membebankan Ansor dalam penyelenggaraan pendidikan politik dan pemecahan konflik-konflik yang terjadi pada masyarakat NU.

\section{Upaya untuk mengatasi kendala dalam penyelenggaraan pendidikan politik generasi muda di GP Ansor Jawa Barat}

Upaya yang dilakukan untuk mengatasi kendala terkait apatisme masyarakat NU 
terhadap gerakan Ansor Jawa Barat yaitu melalui penyuluhan keagamaan dalam bentuk pengajian dari mesjid ke mesjid yang dilakukan oleh para pengurus, senior, dan ulama-ulama NU. Penyuluhan keagamaan yang disisipkan isu-isu ke-Indonesia-an. Kemudian, pemberdayaan organisasi NU yaitu revitalisasi organisasi pelajar NU seperti IPNU dan organisasi kemahasiswaan PMII. Upaya mengatasi masalah keuangan organisasi yaitu amal usaha, iuran anggota, kerja sama dengan pesantren tempat diselenggarakannya program pendidikan politik, dan adanya bantuan dari NU dan alumni merupakan langkah pemecahan masalah terkait pendanaan organisasi. Selanjutnya terkait efektifitas pendistribusian kader, dilakukan seleksi dan verifikasi agar mampu menempatkan kader sesuai dengan kapasitas dan potensi kader. Meskipun membutuhkan waktu yang cukup panjang, namun hal ini diperlukan demi kebaikan kader dan organisasi. Dan upaya terakhir yaitu melalui optimalisasi potensi organisasi dilakukan sebagai jawaban atas kurangnya daya dukung pemerintah dalam penyelenggaraan pendidikan politik.

\section{Pembahasan Penelitian}

Cara pandang organisasi kepemudaan GP Ansor Jawa Barat dalam memaknai pendidikan politik, kepemimpinan lintas budaya, dan budaya politik Pancasila

Pedidikan politik GP Ansor merupakan langkah yang ditempuh untuk membentuk kader yang mampu pribadi mandiri sebagai insan politik. Dalam konteks sosial, ekonomi, dan budaya, pendidikan politik tidak menonjol pada arah kecerdasan (intelektual) namun lebih pada kecerdasan moral individu dalam berhubungan dengan individu lain dan masyarakatnya. Hal ini menggambarkan bahwa seseorang yang melek politik atau insan politik akan lebih mudah berbaur dengan masyarakatnya, karena mampu berhubungan dengan penuh tanggung jawab dan sadar akan kedudukannya dalam masyarakat.
Seorang ahli yaitu Hajer dalam buku political education dari Robert Brownhill dan Patricia Smart dalam Sadeli, dkk (2009, hlm. 19) mengatakan bahwa, pendidikan politik adalah usaha membentuk manusia menjadi partisipan yang bertanggung jawab dalam politik, sehingga masyarakat mengerti tentang hak politiknya. Senada dengan pendapat Hajer, Kartono (2009, hlm. 64) menyebutkan bahwa:

Pendidikan politik adalah upaya edukatif yang intensional, disengaja dan sistematis untuk membentuk individu sadar politik, dan mampu menjadi pelaku politik yang bertanggung jawab secara etis/moril dalam mencapai tujuan-tujuan politik.

GP Ansor menyadari bahwa pendidikan politik merupakan bentuk persiapan bagi organisasi dalam memenangkan pertarugan politik kekuasaan. Tidak bisa dipungkiri bahwa pendidikan politik GP Ansor juga merupakan wana untuk membentuk kader yang mampu menduduki tampuk kekuasan dalam pemerintahan. Hal ini dilatarbelakangi atas realitas yang ada bahwa untuk mencapai perubahan dan perbaikan secara masif, diperlukan kekuatan sistem yang menuntut untuk menciptakan kebijakan yang mendukung visi dan misi GP Ansor yang tidak lain sejalan dengan Indonesia. Komitmen NU dan GP Ansor tidak lain adalah untuk menjaga keutuhan NKRI dari segala bentuk ancaman yang datang baik bersifat internal maupun eksternal. Ancaman dari dalam muncul atas ketidakadilan yang dirasakan warga negara pada berbagai daerah dan karakteristik bangsa Indonesia yang multikultural dan plural yang cenderung mengarah pada terjadinya konflik horizontal apabila tidak ada sosok yang mampu mengelola konflik tersebut. Begitu pula ancaman yang berasal dari luar seperti pesatnya arus globalisasi justru dapat menggerus keutuhan NKRI jika tidak mampu untuk disaring.

Kesadaran tinggi warga negara terhadap hak dan kewajibannya merupakan salah satu 
indikator terbentuknya civil society Indonesia. Hal tersebut disadari penuh oleh GP Ansor bahwa pendidikan politik dalam sudut pandang politik sehari-hari merupakan upaya menciptakan suasana masyarakat madani Indonesia. GP Ansor memandang civil society Indonesia dapat terwujud jika perilaku bangsa Indonesia berlandaskan pada nilai-nilai-Islam dan Pancasila sebagai nilai luhur bangsa Indonesia. Maka karakter kepemimpinan menjadi hal yang wajib dimiliki agar mampu membimbing diri para kader dalam menjalankan hak dan kewajibannya. "Setiap orang di antara kamu adalah pemimpin, dan setiap pemimpin bertanggung jawab atas kepemimpinannya" (HR Bukhari dan Muslim). Hadist diriwayatkan Bukhori Muslim ini mendasari GP Ansor untuk membentuk kader yang memiliki karakter kepemimpinan dalam dirinya masing-masing.

Demi mencapai civil society Indonesia, secara umum pendidikan politik bertujuan seperti tercantum dalam Inpres RI No. 12 tahun 1982 yaitu:

Menciptakan generasi muda Indonesia yang sadar akan kehidupan berbangsa dan bernegara berdasarkan Pancasila dan UUD 1945 sebagai salah satu usaha untuk membangun manusia seutuhnya, yang perwujudannya akan tercermin dalam sejumlah ciri watak dan kepribadiannya sebagai berikut: 1) Sadar akan hak dan kewajiban serta tanggung jawab terhadap kepentingan bangsa dan negara yang terutama diwujudkan melalui keteladan; 2) Secara sadar taat pada hukum dan UndangUndang Dasar; 3) Memiliki disiplin pribadi, sosial, dan nasional; 4) Berpandangan jauh ke depan serta memiliki tekad perjuangan untuk mencapai kehidupan yang lebih maju, yang didasarkan pada kemampuan objektif bangsa; 5) Secara sadar mendukung sistem kehidupan nasional secara demokratis; 6) Aktif dan kreatif dalam kehidupan berbangsa dan bernegara khususnya dalam usaha; 7) Aktif menggalang persatuan dan kesatuan bangsa dengan kesadaran akan keanekaragaman bangsa; 8) Sadar akan perlunya pemeliharaan lingkungan hidup dan alam secara selaras, serasi, dan seimbang; 9) Mampu melaksanakan penilaian terhadap gagasan, nilai, serta ancaman yang bersumber dari luar Pancasila dan UUD 1945 atas dasar pola pikir atau penalaran logis mengenai Pancasila dan UUD 1945

Oleh karena itu, karakter kepemimpinan lintas budaya menjadi suatu keharusan yang dimiliki oleh setiap kader baik dalam posisinya sebagai pemegang kekuasaan maupun posisinya sebagai warga negera biasa. Diyakini bahwa tidak akan mungkin tercipta suatu keharmonisan Indonesia jika hanya penguasa yang memiliki karakter kepemimpinan lintas budaya. Maka, GP Ansor menghendaki seluruh kader Ansor harus memiliki karakter kepemimpinan lintas budaya. Hal ini yang menjadi inti dari teori kepemimpinan situasional yang menjadi dasar kepemimpinan lintas budaya yaitu adanya kematangan pemimpin dan warga negara yang dipimpinnya sehingga terjadi pola komunikasi yang efektif di dalamnya. Kepemimpinan lintas budaya menjadi tipe ideal yang dibutuhkan Indonesia mengingat untuk mencapai tujuan bersama di atas budaya yang berbeda. Akiga dan Lowe (2004, hlm. 2) mendefinisikan kepemimpinan lintas budaya sebagai berikut.

the ability of an individual (the leader) to intentionally and unequally influence and motivate members of a culturally different group toward the achievement of a valued outcome by appealing to the shared knowledge and meaning systems of that culturally different group

Karakater kepemimpinan lintas budaya sangat diperlukan Indonesia yang memiliki karakteristik kebudayaan yang beraneka ragam. Suatu hal yang mustahil ketika Indonesia harus diseragamkan menjadi satu kebudayaan Indonesia di atas beraneka ragamnya kebudayaan tersebut. Namun juga keanekaragaman tersebut tidak mungkin pula dibiarkan secara alami karena dapat merongrong integritas bangsa Indonesia dengan memunculkan sikap etnonasionalisme yang berujung pada separa- 
tisme. Maka, pemimpin yang memiliki karakteristik kepemimpinan lintas budaya ditujukkan untuk menciptakan bangsa Indonesia menjadi manusia antarbudaya yang mampu bersatu demi mewujudkan tujuan Indonesia tanpa melepas karakter budaya lokal. Budimannsyah dan Suryadi (2008, hlm. 175) mendeskripsikan bahwa manusia antarbudaya memperlihatkan sikap agak etnosentris dan lebih menghargai perbedaan budaya dengan perasaan dan perilaku yang toleran dan bisa memadukan perbedaan-perbedaa. Tidak bisa dipungkiri bahwa realitas kenegaraan yang berdiri di atas kemajemukan memberikan peluang besar terjadinya perilaku etnosentris dan etnonasionalis yang dapat berdampak pada perpecahan. Melalui pendidikan, hal tersebut dapat diminimalisir dengan menghasilkan manusia antarbudaya yang memiiki karakter kepemimpinan lintas budaya. Hal ini menjadi agenda GP Ansor sebagai organisasi kepemudaan yang memiliki komitmen terhadap persatuan Indonesia di atas keanekargaman budaya bangsa.

Salah satu kompetensi yang harus dimiliki pemimpina lintas budaya adalah komunikasi antarbudaya. Sitaram (Budimannsyah dan Suryadi, 2008, hlm. 165) mendefinisikan komunikasi antarbudaya sebagai seni untuk memahami dan saling mengerti antara khalayak yang berbeda kebudyaan. Selanjutnya Samovar, dkk. (2010, hlm. 13) menyebutkan:

Komunikasi antarbudaya terjadi ketika anggota dari satu budaya tertentu memberikan pesan kepada anggota dari budaya yang lain. Lebih tepatnya, komunikasi antarbudaya melibatkan interaksi antara orang-orang yang persepsi budaya dan sistem simbolnya cukup berbeda dalam suatu komunikasi.

Komunikasi menjadi kunci utama berjalannya roda organisasi. Begitu pula diperlukan komunikasi yang efektif dari pemimpin terhadap warga negara yang dipimpinnya. Pendidikan politik GP Ansor ditujukan untuk menciptakan karakter kepemimpinan lintas budaya bagi para kader sehingga mampu memiliki perilaku politik yang berlandaskan pada nilai-nilai Pancasila. Batawi (2013, hlm. 30) menyebutkan bahwa pendidikan politik sebagai proses penyampaian budaya politik bangsa, mencakup cita-cita politik maupun norma-norma operasional dari sistem organisasi politik yang berdasarkan nilai-nilai Pancasila. Pemahaman lintas budaya yang dimiliki kader memberikan dorongan untuk membentuk situasi politik yang mencerminkan pluralistik seperti yang terkandung dalam Pancasila. Maliki (2010, hlm. 179) mengatakan:

Kondisi yang diyakini bisa memperkuat budaya politik pluralistik yaitu (1) wawasan kebangsaan yang tidak mematikan pluralisme, (2) budaya multikultural yang kuat, (3) penyelenggara birokrasi pemerintah yang terbuka, (4) generasi yang mewarisi budaya positif untuk pluralisme politik, dam (5) komunitas agama yang toleran dan kohesif.

Pendidikan politik dalam membentuk generasi muda yang memiliki karakter kepemimpinan lintas budaya tidak lain adalah ditujukan untuk mencapai civil society Indonesia yang dapat dicapai melalui sistem politik yang berlandaskan pada Pancasila. Pendidikan politik diharapkan dapat membentuk perilaku politik kader sehingga dapat membentuk suatu sistem politik yang berakar pada Pancasila. Gaffar (2000, hlm. 99) mengatakan teori tentang budaya politik merupakan salah satu bentuk teori yang dikembangkan dalam memahami sistem politik. Maka, dalam membentuk budaya politik Pancasila haruslah dipahami sistem politik yang berlandaskan Pancasila. Sebagai upaya membentuk suatu sistem politik, langkah awal yang dibangun adalah perilaku politik masyarakatnya. Hal ini disadari GP Ansor bahwa pendidikan politik diselenggarakan untuk membentuk karakter kepemimpinan bagi para kader sehingga mampu mencerminkan perilaku 
politik yang berlandaskan Pancasila. Kuswandi (2010, hlm. 40) menyebutkan

perilaku politik lebih mengarah pada tindakan-tindakan yang disebabkan cara pandang individu atas sistem politik yang dilaksanakan dalam aktivitas berpolitik dia. Sedangkan budaya politik lebih berkonotasi pada pelembagaan dari perilaku politik warga negara yang telah menyatu dalam aktivitas sosial dan politik".

Hal inilah yang mendasari bahwa awal terbangunnya budaya politik Pancasila adalah terbentuknya perilaku politik dari para generasi muda Ansor yang tidak lain dibangun melalui pendidikan politik. Karakter kepemimpinan lintas budaya menjadi dasar utama yang harus dimiliki kader sehingga mampu menjalankan perilaku kehidupan yang mencerminkan Pancasila dalam kehidupan sehari-hari seperti yang diusung oleh GP Ansor yaitu mengamalkan nilai-nilai Pancasila dalam semua aspek kehidupan salah satunya dalam aspek politik.

Peran organisasi kepemudaan GP Ansor Jawa Barat dalam membentuk karakter kepemimpinan lintas budaya pada generasi muda yang berasaskan pada nilai-nilai Pancasila melalui penyelenggaraan pendidikan politik

Peran yang diberikan PW GP Ansor Ansor Jawa Barat adalah melakukan pendidikan dan pelatihan kepemimpinan kader demi terbentuknya kararakter kepemimpinan tersebut. Adapun pendidikan dan pelatihan kepemimpinan kader tersebut meliputi sektor strategi keumatan dan kebangasaan yaitu terkait kepemimpinan isu, kepemimpinan gerakan kultural, dan kepemimpinan ruhiyah atau spiritual. Kepemimpinan isu berfokus pada isu pluralisme, perubahan sosial, penuntasan problem sosial, dan demokrasi. Adapun kepemimpinan gerakan kultural berfokus pada menguatkan tradisi NU dan local culture. Sedangkan kepemimpinan ruhiyah atau spiritual berfokus pada rujukan atau referensi keagamaan. Ketiga kepemimpinan ini dapat diistilahkan sebagai kepemimpinan lintas budaya yang menjadi agenda PW GP Ansor Jawa Barat. Pelatihan kepemimpinan yang dilakukan GP Ansor merupakan upaya menjadikan GP Ansor dan kader sebagai bagian dari kehidupan kenegaraan dan mampu memberikan kemanfaatan bagi Indonesia. Lao Tzu lebih dari 2000 tahun yang lalu (Sashkin dan Sashkin, 2011, hlm. 7) menyebutkan Good leadership consist of doing less and being more (kepemimpinan yang baik adalah mengerjakan sedikit dan menjadi semakin lebih baik). Filososi ini menjadi acuan bahwa efektifitas kepemimpinan sangat diperlukan dalam setiap aspek kehidupan kenegaraan. Kepemimpinan lintas budaya menjadi harapan tersendiri dalam menyelesaikan permasalahan Indonesia yang muncul di atas perbedaan karakteristik bangsa.

Dalam pandangan NU dan PW GP Ansor Jawa Barat, pendidikan politik yang dibangun dalam membentuk karakter kepemimpinan lintas budaya pada generasi muda NU baik itu dalam mempersiapkan kader untuk terjun dalam dunia politik maupun kemasyarakatan, tidak lain adalah untuk merubah dan memperbaiki bangsa Indonesia sesuai dengan ajaran Islam (Aswaja) dan Pancasila. Demi terciptanya hal ini, NU dan GP Ansor harus memiliki peran yang signifikan sehingga dapat melanjutkan perjuangan para ulama Aswaja terdahulu yang mengharapkan terjadinya harmonisasi antara ajaran Islam dengan budaya lokal yang hidup di Indonesia. pendidikan politik diselenggarakan untuk membentuk masyarakat NU dan bangsa Indonesia pada umumnya menjadi warga negara Indonesia sebagai Mabadi Khaira Ummah. Mabadi Khaira Ummah adalah gerakan pembentukan identitas dan karakter warga NU melalui penanaman nilai-nilai yang dapat dijadikan prinsip-prinsip dasar (Mabadi) untuk menjadi umat yang terbaik (Khaira Ummah). Adapun nilai-nilai tersebut meliputi $a s s h i d q u, a l$ amanah/al wafa bil ahdi, atta'awun, al adalah, dan al istiqomah. 
Bagi NU dan GP Ansor, pendidikan politik menjadi sarana perubahan dan perbaikan atas penyimpangan nilai-nilai yang terkandung dalam UUD 1945 saat ini yang justru tidak mencerminkan nilai-nilai luhur bangsa Indonesia. Hal tersebut mendorong NU dan GP Ansor untuk membentuk karakter kepemimpinan lintas budaya bagi generasi muda dan warga NU untuk kembali pada khitah 1945 baik dalam posisinya sebagai pemegang kekuasaan maupun sebagai masyarakat biasa pada umumnya. Adapun khitah 1945 dalam pandangan NU dan GP Ansor yaitu nilai-nilai yang melandasi ideologi adalah agama, tradisi, modernitas, budaya, dan aswaja sehingga menghasilkan dasar negara yang berpegang pada nilai ketuhanan, kemanusiaan, kebangsaa, kerakyatan, dan keadilan. Nilai-nilai tersebut dapat berdampak pada bentuk negara yang berpegang pada prinsip persatuan dan kesatuan dengan sistem politik permusyawaratan, sistem ekonomi berpegangan pada kekeluargaan dengan kondisi sosial kemasyarakatan yang bersifat komunitarian dengan mengedepankan budaya gotong royong. Kondisi tersebut diyakini dapat membawa Indonesia sebagai negara berdaulat, bangsa yang bermartabat, dan masyarakat yang maju sejahtera.

\section{Metode pembelajaran politik di GP Ansor Jawa Barat dalam membentuk karakter kepemimpinan lintas budaya dalam mewujudkan budaya politik Pancasila}

Pada dasarnya pendidikan politik GP Ansor merupakan upaya membentuk kader yang memiliki pemamahaman politik secara teoritis sekaligus praktis. Brownhill dan Smart (1989, hlm. 104) berpendapat

we shall use Stradling's proposals for such a curriculum as a checklist for deciding on priorities. He examines the contents of the political curriculum by dividing into three sections: knowledge, skills, and attitudes and procedural values. He further divides knowledge into propositional knowledge, and practical knowledge and understanding: skills into intelectual skills, acion skills, and communication skills.

Berdasarkan pendapat tersebut, kurikulum yang harus ada dalam pendidikan politik meliputi pengetahuan, keterampilan, dan nilai prosedural. Ketiga bagian tersebut harus ada dalam pelaksanaan pendidikan politik. Pengetahuan sangat diperlukan sebagai landasan pemahaman untuk bertindak politik. Pengetahuan ini lebih bersifat teoritis, sedangkan keterampilan lebih bersifat aplikatif yaitu penerapan dari pengetahuan politiknya dalam kehidupan. Perlu adanya suatu nilai prosedural untuk dijadikan acuan dan batasan dalam melaksanakan tindakan politiknya.

Pada ketiga bagian tersebut, terlihat bahwa dalam pendidikan politik bukan hanya ditekankan dalam hal pemahaman politik warga negara yang bersifat teoritis saja, namun juga perlu adanya suatu aksi atau tindakan politik dari warga negara setelah memiliki pemahaman politik tersebut. Hal ini didasari bahwa pendidikan politik bukan hanya menjadikan manusia yang pintar politik secara intelektualis saja, namun seperti diungkapkan Kartono (2009, hlm. 66) bahwa pendidikan lebih menekankan pada kemampuan mawas situasinya secara kritis, menentukan sikap yang benar, melatih ketangkasan aksi/berbuat.

Selanjutnya, Brownhill dan Smart (1989, hlm. 110-111) menyebutkan kurikulum pendidikan politik yaitu sebagai berikut: a) $A n$ ethical based should be developed, which would include respect for others, tolerance, and an understanding of the principle of treating others as one would like to be treated oneself; b) A consideration of how rules can be changed, and generally of how to get things done; c) Nature of rules and authority; d) Concept of obligation to legitimate authority; e) An understanding of some basic political concepts, e.g. freedom, equality, justice, the rule of law, and some of the arguments related o these concepts; f) An 
understanding of the basic structure of central and local government; g) Some understanding of the working of the national and international economy; h) Some knowledge of recent British and international history; i) Self-analysis.

Sebagai langkah realisasi dalam membentuk kader yang memiliki pemahaman secara teoritis dan praktis, maka GP Ansor menyusun program-program sedimikian rupa sehingga mampu terlaksana secara efektif dan memberi hasil yang positif. Adapun program-program pendidikan politik yang diselenggarakan adalah melalui beberapa tahap yaitu pengkaderan, pengembangan, promosi dan pendistribusian kader. Program pengkaderan yang dilakukan GP Ansor yaitu Pelatihan Kepemimpinan Dasar (PKD), Pelatihan Kepemimpinan Lanjutan (PKL) dan Pelatihan Kepemimpinan Nasional (PKN). Adapun yang menjadi kewenangan PW GP Ansor Jawa Barat adalah PKD dan PKL. PKD pada dasarnya merupakan kewengan Pimpinan Cabang GP Ansor pada tingkat kabupaten/kota, namun dalam keadaan tertentu PKD menjadi kewenangan PW GP Ansor tingkat provinsi.

Materi pokok yang diberikan dalam pelaksanaan PKD yaitu Ahlussunnah wal jama'ah I, ke-Indonesiaan dan kebangsaan, keNU-an I, ke-GP Ansor-an I, amaliyah dan tradisi keagamaan NU, dan pengantar dasar keorganisasian. Selain materi pokok tersebut, dapat ditambahkan materi muatan lokal atau materi pendukung meliputi materi-materi yang disesuaikan dengan kebutuhan lokal, potensi daerah, dan kepentingan kaderisasi di daerah yang bersangkutan. Sedangkan materi pokok PKL meliputi Ahlussunnah wal jama'ah II, keNU-an II, ke-GP Ansor-an II, kepemimpinan efektif, manajemen organisasi, komunikasi, kerjasama dan networking, pengambilan keputusan dan pemecahan masalah, manajemen konflik, dan lobby dan negosiasi.

Pendidikan dan pelatihan kepemimpinan kader merupakan langkah yang harus dilakukan sebagai upaya menciptakan kader yang berkualitas. Luthans (Puspitasari, dkk. 2014, hlm. 3) mengungkapkan tiga faktor yang mempengaruhi kepemimpinan lintas budaya, yaitu nilai-nilai pribadi, latar belakang pemimpin dan kemampuan interpersonal. Materimateri yang disampaikan dalam pendidikan dan pelatihan kepemimpinan merupakan upaya penanaman nilai-nilai budaya Indonesia dan Aswaja kepada kader sehingga memiliki rasa dan kesadaran akan cinta Indonesia dan memeliharanya sesuai dengan ajaran Islam Aswaja. Selanjutnya, Yukl (Puspitasari, dkk. 2014, hlm. 3) juga memaparkan faktor-faktor yang mempengaruhi kepemimpinan lintas budaya antara lain variabel budaya nasional dan variabel situasional. Materi terkait Aswaja dan ke-Indonesia-an adalah materi utama yang terdapat dalam kurikulum pendidikan dan pelatihan kepemimpinan kader. Mengingat kondisi Indonesia yang multikultural dan plural, karakter kepemimpinan yang harus dimiliki kader adalah berdasar pada karakteristik budaya bangsa. Mengingat komitmen NU yang mengusung prinsip pengamalan Islam yang tidak bertentangan dengan tradisi budaya bangsa menjadikan kepemimpinan lintas budaya adalah bagian yang tidak bisa dilepaskan dalam penyelenggaraan pendidikan dan pelatihan kepemimpinan kader.

Metode pembelajaran politik dalam pelatihan kepemimpinan tersebut meliputi ceramah, brainstorming, diskusi, focus group discussion (FGD), game dan dinamika kelompok, penugasan, studi kasus, praktek, rihlah/turun lapangan, dan pengamatan proses. Seperti diungkap sebelumnya bahwa pendidikan politik yang dilakukan GP Ansor menekankan pada pemahaman teoritis dan praktis bagi para kader. Maka, metode yang dilakukan mengikuti pendekatan yang menyentuh kognisi, afeksi, dan psikomotor. Hal ini disadari bahwa kader diharapkan bukan hanya memiliki pemahaman namun harus mampu melakukan tindakan. 
Setelah melawati pelatihan kader, langkah selanjutnya adalah pengembangan kader yang diorientasikan untuk mempersiapkan kader pada jenjang pendidikan kader yang lebih tinggi dan mengembangkan kompetensi dan potensi khusus kader pada bidang tertentu. Pengembangan diorientasikan untuk mempersiapkan kader pada jenjang pendidikan kader yang lebih tinggi dilakukan dalam bentu diskusi, kursus Aswaja, pelatihan kepemimpinan, dan/atau pendidikan bela negara. Sedangan pengembangan diorintasikan untuk mengembangkan kompetensi dan potensi khusus kader pada bidang tertentu dilakukan dalam bentuk perekrutan pada kegiatan dan keanggotaan atau kepengurusan Banser, pelatihan kecakapan hidup, pelatihan BMT, pelatihan pengembangan profesi, dan/atau pelatihan-pelatihan pengembangan kader sesuai kebutuhan.

Tahapan terakhir dalam rangkaian pendidikan politik GP Ansor yaitu promosi dan distribusi kader. Promosi kader dilakukan dengan menempatkan kader pada struktur kepengurusan. Sedangkan distribusi kader dilakukan dengan menempatkan kader pada lembaga, institusi, maupun profesi tertentu sesuai dengan kapasitas kader dan kepentingan organisasi. Strategi distribusi kader dilaksanakan secara sinergis dengan kondisi dan kebutuhan setiap tingkatan. Promosi dan distribusi kader merupakan bentuk lanjutan setelah mengalami proses pendidikan politik selama di GP Ansor. Kematangan dan kapasitas kader sangat menentukan dalam promosi dan distribusi kader. Dalam tahapan ini pula, karakter kepemimpinan lintas budaya dirasa telah dimiliki oleh para kader setelah melewati seluruh tahapan materi kepemimpinan dan keIndonesia-an dan diharapkan dapat berdampak baik bagi Indonesia seperti menjaga keutuhan NKRI melalui posisi dan peran kader dalam lembaga pemerintah maupun masyarakat. Selain itu, pemahaman Islam dan Pancasila dapat menjadi pengamalan utama dalam setiap aspek kehidupan, terlebih terkait budaya politik Indonesia agar mampu berlandaskan pada nilainilai Islam dan Pancasila.

\section{Kendala yang dihadapi dalam penyelenggaraan pendidikan politik generasi muda di GP Ansor Jawa Barat}

Demi terjaganya keutuhan NKRI dengan segala khasanah kekayaan budaya bangsa di dalamnya yang sejalan dengan komitmen NU dan GP Ansor, pendidikan politik menjadi tugas penting yang mesti diselenggarakan sehingga mampu membentuk masyarakat NU dan kader Ansor memiliki karakter kepemimpinan baik dalam posisinya sebagai pemimpin maupun sebagai warga negara pada umumnya. Kesadaran akan pentingnya hal ini mendorong NU dan GP Ansor untuk terus mempersiapkan diri demi terciptanya kondisi masyarakat yang dewasa sehingga mampu mewujudkan visi dan misi NU dan GP Ansor serta terbentuknya civil society Indonesia.

Namun dalam realisasinya, penyelenggaraan pendidikan politik yang ditujukan untuk membentuk kader yang memiliki karakter kepemimpinan dan mampu mandiri dalam segala bidang akan ditemui beberapa kendala yang menjadi agenda untuk dipecahkan. Kendala utama yang dihadapi GP Ansor terletak pada permasalahan klasik yaitu kesadaran masyarakat NU terhadap pentingnya gerakan NU dan GP Ansor sebagai bagian penting dalam upaya menjaga keutuhan NKRI. Kartono (2009, hlm. 72-73) berpendapat bahwa kesulitan penyelenggaraan pendidikan politik yaitu antara lain sebagai berikut: a) Amat sulit menyadarkan rakyat akan kondisi diri sendiri yang diliputi banyak kesengsaraan dan kemiskinan, sebagai akibat terlalu lamanya hidup dalam iklim penindasan, penghisapan, dan penjajahan, sehingga mereka menjadi terbiasa hidup dalam serba kekurangan dan ketertinggalan. Sulit mendorong mereka ke arah konsientisasi diri mengungkapkan segala problema yang tengah 
dialami; b) Apatisme politik dan sinisme politik yang cenderung menjadi sikap putus asa itu mengakibatkan rakyat sulit mempercayai usahusaha edukatif dan gerakan-gerakan politik yang dianggap palsu dan meninabobokan rakyat belaka-; sulit pula untuk mengajak mereka untuk berpikir lain dengan nalar jernih. Bahkan banyak di antara massa rakyat yang takut pada kemerdekaan (dirinya); c) Dengan latar pendidikan yang rendah atau kurang, rakyat kebanyakan sulit memahami kompleksitas situasi sosial dan politik di sekitar dirinya; d) Para penguasa yang otoriter cenderung tidak menghendaki adanya pendidikan politik, karena mereka berkepentingan sekali dengan status quo dan pelestarian rezimnya. Partisipasi aktif dan pengawasan terhadap jalannya pemerintahan oleh rakyat itu tidak dikehendaki, sebab mengurangi kebebasan dan kekuasaan organorgan ketatanegaraan.

NU sebagai sebuah organisasi Islam yang memiliki basis massa paling banyak di Indonesia dihadapkan pada permasalahan cerai berainya masyarakat NU. Tingkat kesadaran masyarakat NU terhadap pentingnya pendidikan politik sebagai upaya perjuangan NU dan GP Ansor dirasakan belum optimal. Pada masyarakat perkotaan, sikap acuh dan hedonisme menjadi faktor utama rendahnya partisipasi terhadap NU dan GP Ansor sehingga konstribusi dan daya dukung terhadap kemajuan dan gerakan NU dan GP Ansor bisa dikatakan rendah. Begitu pula pada masyarakat pedesaan yang lebih cenderung berpikir pragmatis yang hanya mementingkan kebutuhan primer saja. Memang tidak bisa dipungkiri hal tersebut adalah suatu kenyataan yang dilandasi atas kebutuhan yang tidak lepas dalam kehidupan masyarakat. Pada kenyataan, rendahnya kesadaran tersebut berdampak pada berkurangnya kekuatan politik bagi NU dan GP Ansor dalam mencapai gerakannya

Kendala lain yang dianggap memberikan dampak pada penyelenggaran pendidikan politik
GP Ansor adalah terkait keuangan organisasi.. Penyelenggaraan pendidikan politik melalui program pelatihan kepemimpinan dasar (PKD) dan pelatihan kepemimpinan lanjutan (PKL) serta program-program lainnya merupakan kegiatan yang memerlukan pendanaan. Perhatian lebih ditatapkan pada kebutuhan dana dalam pendistribusian kader yang dipersiapkan untuk pertarungan politik kekuasaan. Kita ketahui bahwa ongkos politik demokrasi dalam pemilihan umum sangatlah besar sehingga memerlukan dana yang cukup untuk menggapai kemenangan. Hal ini disadari membutuhkan fokus pemecahan demi tercapainya tujuan.

Terkait pendistribusian kader, hal ini pula menjadi kendala tersendiri ketika karakteristik, kapasitas, dan potensi kader yang beraneka ragam dan banyak menuntut GP Ansor lebih jeli untuk mampu menyalurkan minat dan potensi tersebut secara tepat. Mengingat kompetensi dan kompetisi di Jawa Barat yang cukup ketat membuat GP Ansor harus mampu mempersiapkan kader yang kompeten dan memilah posisi yang tepat sehingga distribusi kader lebih efektif dan memiliki daya guna. Terakhir kendala yang ditemui adalah daya dukung dari pemerintah terhadap penyelenggaraan pendidikan politik bagi generasi muda. GP Ansor menyadari bahwa pendidikan politik memiliki peran penting dalam usaha mencerdaskan generasi muda. Bukan melulu dalam bidang politik, namun dalam bidang-bidang yang lainnya meskipun pada dasarnya lebih cenderung pada pemahaman dan perilaku politik. Bukan suatu hal mudah dalam merealisasikan pendidikan politik tersebut sehingga diperlukan kerjasama dan daya dukung pemerintah agar mampu terlaksana dengan baik. Memang diakui bahwa pendidikan politik yang dilakukan GP Ansor dapat terlaksana meskipun dihadapkan pada kurangnya daya dukung pemerintah. Namun efektifitas dan output yang dihasilkan akan lebih optimal jika ada dukungan dari pemerintah. 
Baik itu bersifat bantuan dana, penyediaan sarana dan media, ataupun program pemerintah yang mampu menjadi penguatan terhadap apa yang telah dilakukan GP Ansor. Sampai saat ini belum dirasakan dukungan optimal dari pemerintah dalam menyukseskan penyelenggaraan pendidikan politik ataupun program yang mampu memberikan penguatan terhadap pendidikan politik yang diseenggarakan baik itu dalam media massa, penyuluhan, atau lainnya.

\section{Upaya untuk mengatasi kendala dalam penyelenggaraan pendidikan politik generasi muda di GP Ansor Jawa Barat}

Upaya yang dilakukan dalam menghadapi permasalahan rendahnya kesadaran masyrakat dan generasi muda NU adalah melalui penyuluhan keagamaan dalam bentuk pengajian dari mesjid ke mesjid yang dilakukan oleh para pengurus, senior, dan ulama-ulama NU. Kendala apatisme masyarakt NU banyak ditemui pada masyarakat perkotaan dengan kondisi masyarakat yang hedonis dan bersifat acuh terhadap gerakan Ansor dan NU. Melalui penyuluhan keagamaan seperti dalam pelaksanaan peringatan hari besar Islam (PHBI) diharapkan mampu mengangkat kesadaran masyarakat NU. Organiasi NU dan GP Ansor sebagai organisasi Islam yang komitmen terhadap NKRI salalu mengangkat isu-isu keIndonesia-an dalam setiap pengajian keagamaan. Hal ini ditujukan sebagai upaya meningkatkan kepekaan masyarakat NU terhadap kondisi realitas Indonesia saat ini. Pemberian pemahaman ke-Indonesia-an yang dibalut dalil-dalil keagamaan memberikan suatu dorongan dan stimulus bagi masyarakat NU sehingga mampu memandang Indonesia dengan cara pandang keagamaan yang luas berbeda halnya dengan organisasi Islam yang bersifat radikal yang justru memandang Indonesia dari kacamata agama yang lebih sempit.

Selanjutnya adalah upaya yang dilakukan dalam menghadapi kendala keuangan organisasi. Seperti diungkap sebelumnya bahwa GP Ansor merupakan organisasi kader yang tidak memiliki sumber pendanaan yang tetap. Pada umumnya organisasi kepemudaan atau organisasi kemasyarakatan mendapatkan bantuan keuangan dari pemerintah. Namun diakui GP Ansor sampai saat ini belum merasakan bantuan keuangan dari pemerintah. Bukan dimaksudkan bahwa GP Ansor menjadi anak tiri dari pemerintah, namun hal tersebut dikarenakan GP Ansor memegang prinsip kemandirian sehingga tidak bergantung pada pemerintah. Sebagai realisasi prinsip kemandirian tersebut, program yang dilakukan adalah melalui Baitul Maal wa tamwil (BMT) yang terus digalakan disetiap tingkat kepengurusan GP Ansor. BMT adalah agenda pengembangan ekonomi syariah yang diemban GP Ansor. Hasil yang diharapkan dari pengembangan progrm ini adalah sebagai sarana ekonomi Ansor sehingga kader-kader Ansor menjadi insan mandiri secara ekonomi yang dapat membantu penyelenggaraan pendidikan politik GP Ansor. Pada tahapan selanjutnya mampu menjadi pionir pengembangan ekonomi syariah yang berasaskan Islam dan kerakyatan bagi kehidupan ekonomi kenegaraan. Selanjutnya kendala yang dihadapi adalah terkait pendistribusian kader yang dihadapkan pada potensi yang dimiliki sekian banyak kader Ansor dan kompetisi serta persaingan yang ketat di Jawa Barat menuntut GP Ansor Jawa Barat agar mampu memaksimalkan potensi kader dan mematangkan persiapan distribusi kader sehingga mampu menenmpati posisi yang strategis dalam masyarakat maupun pemerintah. Alangkah disayangkan apabila pendistribusian kader ini tidak mampu maksimal, akan banyak kader yang tidak mampu berperan dan memberikan daya guna bagi dirinya maupun organisasi bahkan bagi Indonesia.

Terakhir dalam menyikapi kendala daya dukung pemerintah, upaya yang dilakukan adalah memaksimalkan potensi organisasi yang telah dibangun bertahun-tahun ke belakang 
lamanya serta peran NU dalam sejarah Indonesia memberikan pandangan positif dari berbagai elemen masyarakat terhadap GP Ansor. Hal tersebut merupakan modal penting yang dimiliki GP Ansor sehingga banyak elemen masyarakat yang mendukung GP Ansor dalam melaksanakan pendidikan politik dan gerakannya. Selain itu, potensi kader dan posisi alumni menjadi modal selanjutnya dalam upaya mensukseskan pendidikan politik GP Ansor. Kematangan kader dan alumni menjadi potensi organisasi yang harus dimaksimalkan. Setidaknya kematangan yang dimiliki kader dan senior dapat berupa tanggung jawab dan rasa memiliki agar mampu mengembangkan organisasi. Seperti diungkap Rivai dan Mulyadi (2013, hml. 48), kematangan adalah:

Bukan kematangan secara psikologis melainkan menggambarkan kemauan dan kemampuan (willingness \& ability) anggota dalam melaksanakan tugas masing-masing termasuk tanggung jawab dalam menyelesaikan tugas tersebut juga kemauan dan kemampuan mengarahkan diri sendiri. Jadi, variabel kematangan yang dimaksud adalah kematangan dalam melaksanakan tugas masing-masing tidak berarti kematangan dalam segala hal.

\section{PENUTUP}

Pendidikan politik dalam pandangan GP Ansor Jawa Barat adalah upaya untuk membentuk karakter kepemimpinan pada generasi muda NU. Karkter kepemimpinan lintas budaya merupakan suatu kesadaran kader Ansor dalam menyikapai karakteristik bangsa Indoonesia yang multikultural dan plural sehingga mampu mencapai tujuan bangsa dan negara yaitu civil society Indonesia di atas kemajemukan bangsa Indonesia. Karakter kepemimpinan lintas budaya menjadi modal utama bagi para kader dalam membangun suatu budaya politik yang berlandaskan pada nilainilai Pancasila sebagai alat dan strategi untuk pencapaian tujuan tersebut. Penyelenggaraan pendidikan politik yang ditujukan untuk membentuk karakter kepemimpinan lintas budaya merupakan realisasi komitmen NU untuk menjaga keutuhan NKRI dan memberikan perubahan Indonesia ke arah yang lebih baik dan diridhoi Alloh. Peran PW GP Ansor Jawa Barat sebagai bagian dari yaitu melakukan pelatihan dan pendidikan kepemimpinan kepada kader untuk membentuk karakter kepemimpinan lintas budaya yang mencerminkan mabadi khaira ummah sehingga dapat merubah dan memperbaiki Indonesia kembali pada khitah yang berakar pada nilai-nilai luhur bangsa Indonesia yaitu khitah 1945 .

Rangkaian pendidikan politik yang diselenggarakan GP Ansor Jawa Barat meliputi pendidikan dan pelatihan kader, pengembangan kader, promosi dan pendistribusian kader. Pendidikan dan pelatihan kader yang diselenggarakan PW GP Ansor Jawa Barat meliputi PKD dan PKL dengan materi pokok ke-NU-an, ke-Indonesia-an dan kebangsaa, manajemen organisasi, dan kepemiminan. Pendekatan yang dilakukan adalah pendekatan pedagogi dan andragogi dengan metode pembelajaran yaitu ceramah, brainstorming, diskusi, focus group discussion (FGD), game dan dinamika kelompok, penugasan, studi kasus, praktek, rihlah/turun lapangan, dan pengamatan proses. Selanjutnya, pengembangan kader diorientasikan untuk mempersiapkan kader pada jenjang pendidikan kader yang lebih tinggi dan untuk mengembangkan kompetensi dan potensi khusus kader pada bidang tertentu. Adapun promosi kader dilakukan dengan menempatkan kader pada struktur kepengurusan dan pendisribusian kader dilakukan dengan menempatkan kader pada lembaga, instansi, dan profei tertentu sesuai kapasitas kader dan kepentingan organisasi.

Penyelenggaraan pendidikan politik yang dilakukan PW GP Ansor Jawa Barat menemui beberapa kendala yaitu apatisme masyarakat 
NU sehingga kekuatan massa NU tidak mampu memperkuat sistem, keuangan organisasi salah satunya untuk pendistribusian kader, efektifitas pendistribusian kader, dan rendahnya daya dukung pemerintah terhadap efektifitas pendidikan politik. Upaya yang dilakukan dalam menghadapi kendala tersebut yaitu melakukan penyuluhan keagamaan dalam bentuk pengajian dan revitalisasi IPNU sebagai media pengembangan potensi pelajar NU, amal usaha dan iuran anggota untuk memperkuat keuangan organisasi, seleksi dan verifikasi sebagai upaya mengefektifkan pendistribusian kader, serta audiensi dengan pemerintah dan memaksimalkan potensi organisasi demi terlaksana penyelenggaraan pendidikan politik yang efektif dan memiliki nilai manfaat.

\section{DAFTAR PUSTAKA}

\section{Buku dan Artikel Jurnal:}

Akiga, dan Kevin B. Lowe. (2004). Encyclopedia of Leadership: CrossCultural Leadership. SAGE Reference Online.

Batawi, J. W. (2013). Tingkat kesadaran politik pemilih pemula dalam pilkada. Jurnal UNIERA. 2 (2). Hlm. 26 - 52.

Brownhiil, R. \& Smart, P. (1989). Political Education. London and New York: Routledge.

Budiardjo, M. (2009). Dasar-Dasar Ilmu Politik. Jakarta: PT Gramedia Pustaka Utama.

Budimansyah, D. \& Suryadi, K. (2008). PKn dan Masyarakat Multikultural. Bandung: Prodi PKn SPs UPI.

Darmawan, C. (2008). Pengantar Ilmu Politik. Bandung : Laboratorium Pendidikan Kewarganegaraan Universitas Pendidikan Indonesia.

Djakfar, Y. (2009). Pendidikan politik warga negara dalam menciptakan demokrasi yang berkualitas. Jurnal Online Dinamika. 2 (3), hlm. 41-46.

Gaffar. A. (2000). Politik Indonesia. Yogyakarta: Pustaka Pelajar.

Harrison, L. (2009). Metodologi Penelitian Politik. Jakarta : Kencana.
Hasbullah. (2009). Dasar-Dasar Ilmu Pendidikan. Jakarta: PT. Raja Grafindo Persada.

Hermawan, I.C. (2013). Revitalisasi pendidikan politik. Jurnal Kajian Pendidikan. 3 (1), hlm. 9 - 26.

Isep. (2013). Peran pendidikan kewarganegaraan sebagai sebagai pendidikan hukum dalam mengupayakan internalisasi hukum di kalangan peserta didik (studi kasus di Madrasah Aliyah Negeri Tanggeung Kabupaten Cianjur). Jurnal Penelitian Pendidikan. 14 (1). Hlm. $13-20$.

Kantaprawira, R. (1984). Sistem Politik Indonesia. Bandung: Sinar Baru.

Kartono, K. (2009). Pendidikan Politik sebagai Bagian dari Pendidikan Orang Dewasa. Bandung : Mandar Maju.

Kencana, I. (2005). Filasafat Politik. Bandung: Mandar Maju.

Kosasih. (2011). Peran Organisasi Kemahasiswaan sebagai Laboratorium Pendidikan Politik Mahasiswa. Skripsi Sarjana pada FPIPS UPI Bandung: Tidak diterbitkan.

Kuswandi, A. (2010). Membangun gerakan budaya politik dalam sistem politik Indonesia. Jurnal Governance. 1 (1). Hlm. $40-50$.

Mulyana, D. \& Rakhmat, J. (2010). Komunikasi Antarbudaya Panduan Berkomunikasi dengan Orang-Orang Berbeda Budaya. Bandung. Remaja Rosdakarya.

Nasution, S. (2009). Metode Research. Jakarta: Bumi Aksara.

Pidarta, M. (2007). Landasan Kependidikanan Stimulus Ilmu Pendidikan Bercorak Indonesia. Jakarta: Rinek Cipta.

Poespowardojo, S. dkk. (1991). Pancasila sebagai Ideologi dalam Berbagai Bidang Kehidupan Bermasyarakat, Berbangsa, dan Bernegara. Jakarta: BP-7 Pusat.

Puspitasari, I. Dkk. (2014). Analisis gaya kepemimpinan lintas budaya ekspatriat (studi penelitian pada PT. Haier Sales Indonesia Jakarta Utara). Jurnal Administrasi Bisnis (JAB). 8 (1). Hlm. 1 10.

Rahman, A. (2001). Pendidikan agama Islam dan pendidikan Islam-tinjauan epistimologi 
dan isi-materi. Jurnal Eksis. 8 (1). Hlm. Suwarno, W. (2009). Dasar-Dasar Ilmu $2053-2059$.

Rivai, V. \& Mulyana, D. (2013). Kepemimpinan dan Perilaku Organisasi. Jakarta: Rajawali Pers.

Rivai. V. dkk. (2014). Pemimpin dan Kepemimpinan dalam Organisasi. Jakarta: Rajawali Pers.

Sadeli, Elly H, dkk. (2009). Bedah Buku Political Education dari Robert Brownhill dan Patricia Smart. Bandung: Kencana Utama.

Samovar, L. dkk. (2010). Komunikasi Lintas Budaya (Communication Between Culture). Jakarta: Salemba Humanika.

Sashkin, M. \& Sashkin, M. G. (2011). PrinsipPrinsip Kepemimpinan. Jakarta: Erlangga.

Siagian, S. (2010). Teori \& Praktek Kepemimpinan. Jakarta: Rineka Cipta.

Sugiyono. (2010). Metode Penelitian Kuantitatif, Kualitatif, dan R\&D. Bandung : Alfabeta CV.

Sukardjo, M. \& Komarudin, U. (2009). Landasan Pendidikan Konsep dan Aplikasinya. Jakarta: PT. RajaGrafindo Persada.

Sulasman, \& Gumilar, S. (2013). Teori-Teori Kebudayaan dari Teori hingga Aplikasi. Bandung: Pustaka Setia.

Surbakti, R. (2010). Memahami Ilmu Politik. Jakarta : Gramedia Widiasarana Indonesia.

Wibowo. (2011). Budaya Organisasi Sebuah Kebutuhan untuk Meningkatkan Kinerja Jangka Panjang. Jakarta: PT Raja Grafindo Persada

Widjaja. A. (1982). Budaya Politik dan Pembangunan Ekonomi. Jakarta: LP3ES.

\section{Peraturan Perundangan:}

Instruksi Presiden RI No. 12 tahun 1982 tentang Pendidikan Politik Generasi Muda

Peraturan Menteri Dalam Negeri RI No. 36/2010 tentang Pedoman Fasilitasi Penyelenggaraan Pendidikan Politik Undang-Undang Dasar Negara Republik Indonesia Tahun 1945.

Undang-Undang Dasar Negara Republik Indonesia tahun 1945

Undang-Undang Republik Indonesia Nomor 20 tahun 2003 tentang Sistem Pendidikan Nasional

Undang-undang Republik Indonesia Nomor 40 tahun 2009 tentang Kepemudaan

\section{Sumber Online dan bentuk lain:}

Anwarudin, A. (2013). Teori-Teori Kepemimpinan (Leadeship Theory) [Online] diakses dari: http://www.slideshare.net/Mazawang/teoriteori-kepemimpinan-28358527 